\title{
MENGANALISIS HUBUNGAN DEBIT POMPA LISTRIK SUBMERSIBLE DC 12 VOLT TERHADAP KETINGGIAN PENAMPUNGAN AIR MELALUI PEMBELAJARAN BERBASIS PROYEK
}

\author{
Ahmad Swandi ${ }^{1}$, Sri Rahmadhanningsih ${ }^{2}$, Sparisoma Viridi ${ }^{3}$ \\ 1) Pendidikan Fisika, Universitas Bosowa, ahmad.swandi@universitasbosowa.ac.id \\ 2) Institut Teknologi Bandung, \\ 3) Institut Teknologi Bandung,
}

\begin{abstract}
Abstrak
Salah satu masalah terbesar bagi petani di musim kemarau adalah kurangnya pasokan air untuk irigasi. Saat ini berbagai jenis pompa telah banyak digunakan, seperti pompa bahan bakar dan pompa dengan listrik PLN. Namun biaya yang dibutuhkan untuk mengoperasikan alat tersebut cukup mahal. Solusi yang ditawarkan adalah menggantinya dengan pompa air submersible DC 12 volt 50 Watt. Tujuan dari penelitian ini yaitu untuk mengetahui produktivitas pompa submersible DC ditinjau dari debit yang dihasilkan untuk berbagai kondisi ketinggian penyimpanan yang digunakan. Penelitian ini merupakan penelitian eksperimen dengan metode Gold Standard Project Based Learning (Gold Standard PBL) yang terdiri dari Menantang Soal atau Pertanyaan, Sustained Inquiry, Autheticity, Suara dan Pilihan Siswa, Refleksi, Kritik dan Revisi, Produk Publik. Hasil dari penelitian ini yaitu ketinggian reservoir berpengaruh terhadap debit yang dihasilkan, terjadi pengurangan debit yang dihasilkan setiap kenaikan ketinggian reservoir 0,5 m. Berdasarkan hasil analisa dengan menggunakan Microsoft Excel diperoleh batas ketinggian maksimum push pump submersible adalah 3,7 m dengan menggunakan selang inch. Hasil penelitian ini dapat menjadi acuan bagi petani atau pengguna untuk menentukan ketinggian tempat penampungan air.
\end{abstract}

Kata kunci: PBL Standar Emas; Pompa Submersible DC

\begin{abstract}
One of the biggest problems for farmers in the dry season is the lack of water supply for irrigation. Currently, various types of pumps have been widely used, such as fuel pumps and pumps with PLN electricity. However, the costs required to operate these tools are quite expensive. The solution offered is to replace it with a 12 volt 50 Watt DC submersible water pump. The purpose of this study, namely to determine the productivity of the DC submersible pump in terms of the resulting discharge for various storage height conditions used. The research is an experimental research through Gold Standard Project-Based Learning (Gold Standard PBL)method consisting of Challenging Problem or Questions, Sustained Inquiry, Autheticity, Student Voice and Choice, Reflection, Critique and Revision, Publict Product. The results of this study, namely the height of the reservoir has an effect on the resulting discharge, there is a reduction in the resulting discharge every $0.5 \mathrm{~m}$ increase in the height of the reservoir. Based on the results of the analysis using Microsoft Excel, it is obtained that the maximum height limit for submersible pump push is $3.7 \mathrm{~m}$ using a $3 / 4$ inch hose. The results of this study can be a reference for farmers or users to determine the height of the water reservoir.
\end{abstract}

Kata kunci: Gold Standard PBL; DC Submersible Pump

\section{Pendahuluan}

Ketersediaan air untuk pengairan tanaman palawija dimusim kemarau sangat perlu diperhatikan. Hal ini disebabkan karena, produktivitas tanaman khusunya palawija sangat ditentukan oleh ketersediaan air untuk pengairan [1]. Tanaman yang tidak mendapatkan pengairan yang cukup akan mati dan mengakibatkan kegagalan panen, sehingga kerugian yang dialami oleh para petani sangat besar. Sistem pengairan tradisonal dengan mengangkut air dengan tenaga manusia sangat tidak efektif [2]. Hal ini disebabkan karena, selain membutuhkan tenaga yang cukup besar, sering kali penyiraman untuk tanaman dalam skala luas tidak maksimal [3]. 
Beberapa kegiatan petani yang dilakukan untuk mengatasi ketersediaan air adalah dengan menggunakan pompa bahan bakar bensin, solar [4], [5]. Hal ini sangat tidak efektif dan justru memberikan kerugian yang lebih besar kepada petani. Pengoperasian pompa BBM sangat boros, selain itu butuh tenaga besar untuk memindahkan pompa dari rumah ke ladang. Selain penggunaan pompa BBM, beberapa petani juga menggunakan pompa listrik PLN. Namun, bagi para petani yang posisi kebun atau persawahan cukup jauh dari sumber listrik PLN menjadi sebuah masalah tertentu. Selain itu daya yang dibutuhkan pompa tersebut cukup besar. Daya yang seharusnya dapat digunakan untuk menyalakan komponen elektronik lainnya harus dialihkan ke pengoperasian pompa listrik PLN [6].

Untuk mengatasi permasalah tersebut diperlukan inovasi penggunaan pompa listrik yang hemat energi dan dapat dipindahkan dari satu tempat ke tempat lain dengan mudah. Salah satu jenis pompa yang bisa digunakan adalah pompa listrik submersibel DC 12 Volt [7]-[9]. Pompa jenis ini merupakan pompa yang dicelupkan langsung kedalam air dengan membutuhkan aliran sumber listrik DC dari aki. Hal ini sangat dinilai efektif sebab, ukuran pompa dan aki yang dibutuhkan relatif kecil dan bisa dipindahkan dengan mudah. Selain itu instalasi peralatan juga dapat dilakukan dengan mudah dan lebih aman. Pompa jenis ini akan lebih efisien dan digunakan dalam waktu yang lama jika aki yang digunakan dapat dicas kembali [10], [11]. Agar hal ini dapat dilakukan, instalasi pompa listrik dengan aki dan panel surya dapat dilakukan jika penggunaan pompa dilakukan dalam durasi yang cukup lama [12]. Beberapa penelitian sebelumnya tentang penggunaan pompa submersible hanya berfokus pada perancangan dan pengujian kemampuan pompa jika dihubungkan dengan panel surya (bambang setiawan). Selain itu, penelitian yang lain melakukan pengujian debit air yang dihaislkan oleh pompa pada ketinggian 4 meter. Penelitian ini tidak menyajikan ketinggian maksimum yang dapat dijangkau oleh pompa submersibe yang digunakan [13].

Namun, bagaimana kemampuan pompa listrik submersibel DC? Apakah mampu mendorong air ke penampungan yang diletakkan pada ketinggian tertentu? Hal ini sangat penting untuk dipelajari, sebab jika ketinggian penampungan dari posisi pompa cukup besar maka pompa submersible DC tidak mampu mendorong air ke penampungan. Sebaliknya jika ketinggian penampungan sangat rendah maka tekanan hisrostatis yang dimiliki oleh air dalam tandon sangat kecil sehingga tidak mampu mendorong air lebih jauh, sehingga pengairan dengan selang panjang tidak bisa dilakukan. Selain itu analisis spesifikasi pompa, penampungan dan aki sangat penting untuk mengetahui apakah penyiraman pada tanaman tertentu dapat dilakukan secara maksimal. Sebagai contoh untuk tanaman padi yang membutuhkan pengairan lebih maksimal dibandingkan tanaman cabe tentu memerlukan ukuran aki dan penampungan yang lebih besar.

Oleh karena itu, perlu dilakukan pengujian pompa submersibel DC terebih dahulu. Dalam penelitian ini rumusan masalah yang perlu dijawab adalah bagaimana efektifitas pompa listrik submersibel DC yang digunakan yang dilihat dari dua indikator yaitu (1) perubahan debit air yang dihasilkan pompa ini seiring dengan perubahan ketinggian aliran penampungan air; (2) seberapa lama waktu yang dibutuhkan untuk mengoperasikan pompa listrik untuk mengisi bak penampungan air. Untuk melaksanakan penelitian ini, tim yang merupakan mahasiswa pascasarjana menerapkan metode Pembelajaran Berbasis Proyek dengan Standar Emas atau yang dikenal Gold Standard Project-Based Learning [14][15].

Project Based Learning atau selanjutnya disebut PBL, menurut Bucks Institute of Education adalah proses pembelajaran dimana mahasiswa mengerjakan sebuah proyek dalam waktu satu minggu sampai satu semester yang bertujuan untuk menyelesaikan masalah riil atau menjawab pertanyaan kompleks [14], [15]. Selain itu mahasiswa diharapkan menjadi kritis dan kreatif dalam menghadapi permasalahan. PBL juga dapat membantu membangun kemampuan komunikasi dan kolaborasi dalam tim. Pada umumnya dosen atau guru menggunakan PBL untuk sistem pembelajarannya sehingga pembelajaran menghasilkan kualitas yang baik dan mencari keterkaitan antara pelaksanaan PBL dengan berbagai variabel seperti pemahaman konsep dan keterampilan berpikir kritis serta pemecahan 
masalah. Misalnya, penelitian yang dilakukan oleh Al-Tabany menggunakan PBL untuk mengetahui pengaruhnya terhadap pemahamar konseptual dan pengembangan keterampilar seperti kolaborasi, berpikir kritis dan pemecahar masalah [15]. Begitu pula dengan penelitian yang dilakukan oleh Trianto yang menyatakan bahwe terjadi peningkatan motivasi belajar dan hasi] belajar mahasiswa meningkat setelar pembelajaran menggunakan model PBL [16] Selain itu, Rashid dan Bakar menyatakan bahwe 20 Ah PBL dapat melatih mahasiswa untuk membinc kemampuan komunikasi dan tim kerja. Namur dari semua penelitian tersebut, PBL sebagiar. besar diaplikasikan oleh pengajar untuk bidang pedagogik dan bagaimana penerapannya didalam kelas. Padahal dengan PBL mahasiswa mampu menunjukkan kemampuannya dengan mengembangkan sebuah produk atau melakukan penelitian berbasis eksperimen untuk digunakan lebih luas dan memperoleh sebuah informasi yang baru [14]. Dengan PBL mahasiswa menyerap banyak pengetahuan untuk digunakan dalam penyelesaian masalah yang dipilih.

\section{Metode}

Penelitian ini merupakan penelitian awal sebelum dilakukan penerapan langsung di masyarakat. Desain penelitian ini menggunakan metode penelitian eksperimen dengan Penerapan Gold Standard Project Based Learning (Gold Standard PBL) melalui 8 langkah [14]. Penelitian ini bertujuan untuk menghasilkan perangkat eksperimen yang bertujuan untuk menganalisis hubungan debit air yang dihasilkan oleh pompa celup DC 12 Volt 50 Watt terhadap ketinggian penampungan air. Perlakuan yang dilakukan dalam penelitian ini adalah menghitung kinerja pompa listrik dengan spesifikasi pompa celup (submersible) DC 12 Volt 50 Watt, 2500 liter/jam dengan daya dorong $5 \mathrm{~m}$ untuk menyuplai kebutuhan air pada penampungan. Objek penelitian yang digunakan adalah pompa listrik submersibel DC 12 volt 50 watt. Secara spesifik, dilakukan pengujian kemampuan pompa dalam mengisi penampungan air.

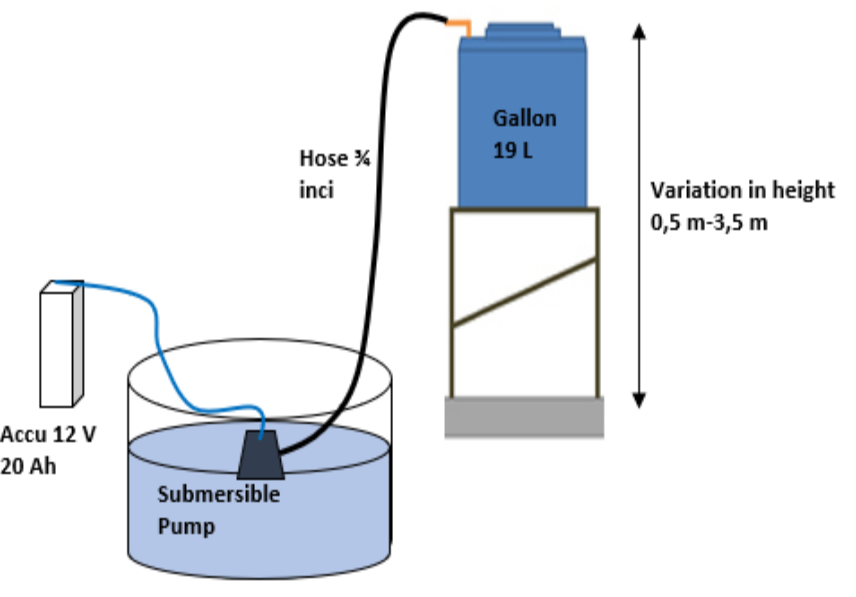

Gambar 1. Pengaturan eksperimen

Peralatan yang digunakan dalam penelitian ini adalah (1) bak ukur (galon) yang digunakan untuk mengetahui debit air dengan volume 19 liter, (2) stopwatch untuk mengukur waktu pengoperasian pompa DC, (3) meteran untuk mengukur ketinggian bak penampungan, (4) Aki 12 volt, 20 Ah sebagai sumber utama ; (5) kabel sebagai penghubung antara komponen elektronik; (6) slang dengan diamater $3 / 4$ inci untuk mengalirkan air dari sumber air ke tempat penampungan.

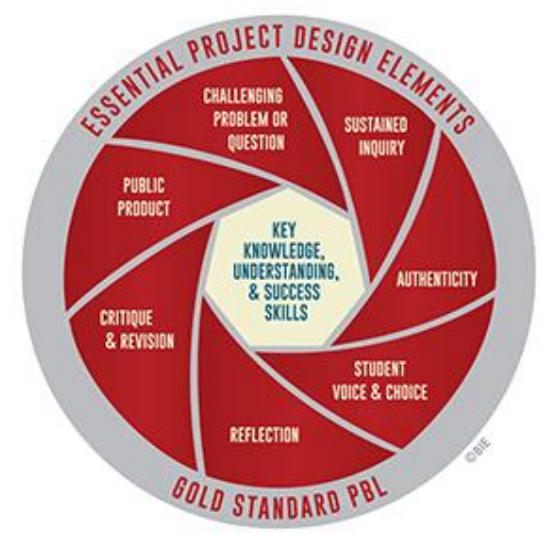

Gambar 2. Tahapan Gold Standard Project Based Learning

Gold Standard PBL melalui 7 langkah yang terdiri dari Challenging Problem or Questions, Sustained Inquiry, Autheticity, Student Voice and Choice, Reflection, Critique and Revision, Publict Product [15]. Pengambilan data primer dilakukan dengan mengalirkan air dari sumber air ke galon (bak penampung) untuk variasi ketinggian dan dilakukan sebanyak 7 kali. Volume galon yang digunakan adalah 19 liter. Debit kemudian dapat 
ditentukan setelah memperoleh waktu pengisian galon hingga penuh. Dengan debit ini juga dapat diperkirakan seberapa lama waktu yang diperlukan untuk mengisi tandon (bak penampungan besar) yang biasa digunakan oleh para petani. Selain itu, dari data yang diperoleh dapat digunakan untuk menganalisis kapasitas aki dan panel surya yang digunakan untuk pengaplikasian dimasyarakat. Hasil pengambilan data penelitian ini selanjutnya dilakukan analisis data dan kemudian disajikan dalam grafik.

\section{Hasil dan Pembahasan}

\subsection{Tahap Tantangan dan Masalah}

Pada tahapan ini, dosen memberikan tantangan kepada tim untuk mendesain sebuah proyek yang berbasis penelitian. Tema dari proyek harus sesuai dengan salah satu topik dari mata kuliah. Dosen memberikan waktu selama 1 minggu kepada tim untuk menentukan tema, tujuan dan luaran yang dihasilkan dari proyek tersebut. Usulan tersebut kemudian didiskusikan dengan dosen dan tim lainnya agar diperoleh banyak tanggapan, perbaikan dan arahan dari dosen. Pada tahapan ini kemudian disepakati tema penelitian berkaitan dengan pengujian pompa celup untuk mengatasi kekeringan dimusim kemarau. Berbagai pertanyaan diberikan oleh dosen antara lain bagaimana spesifikasi pompa celup yang digunakan? Mengapa pompa tersebut dipilih? Tim memberikan informasi bahwa pompa yang digunakan adalah pompa DC 12 volt dengan daya 50 watt. Hal ini dikarenakan jenis pompa tersebut memiliki dimensi yang kecil, mudah digunakan dan dapat dioperasikan hanya dengan menggunakan aki 12 volt.

\subsection{Tahap Kajian Berkelanjutan}

Pada tahapan ini tim diajak oleh dosen untuk selalu bertanya, mencari sumber, dan menggunakan informasi pada proyeknya. Tim kemudian bertanya bagaimana sistem pengujiannya? Besaran apa yang akan diuji dan apa yang diperoleh dari besaran tersebut. Tim selanjutnya melakukan kajian terhadap berbagai sumber berkaitan dengan konsep fisika fluida. Kemudian dilakukan diskusi antara dosen dan tim sehingga disepakati untuk mengkaji produktivitas pompa dengan melakukan pengambilan data debit air yang dihasilkan untuk variasi ketinggian bak penampungan.

\subsection{Tahap Uji Keaslian}

Pada tahap ini dilakukan penyusunan peralatan eksperimen, pengujian dan analisis hasil penelitian. Setelah peralatan diatur seperti pada gambar 1. Dilakukan pengambilan data oleh tim. Data primer yang diperoleh adalah waktu untuk mengisi galon. Kemudian waktu dengan satuan "sekon" dikonversikan ke satuan "jam" sehingga diperoleh debit air yang dihasilkan. Berikut adalah hasil uji coba pompa listrik submersibel DC untuk variasi ketinggian.

Tabel 1. Debit air sesuai ketinggian penampungan (galon)

\begin{tabular}{cccc}
\hline $\begin{array}{c}\text { Ketinggian } \\
(\mathrm{m})\end{array}$ & $\begin{array}{c}\text { waktu } \\
(\text { detik})\end{array}$ & $\begin{array}{c}\text { waktu } \\
(\text { jam })\end{array}$ & $\begin{array}{c}\text { Debit } \\
(\text { Liter/jam })\end{array}$ \\
\hline 0,5 & 31 & 0,008611 & 2206,452 \\
\hline 1 & 35 & 0,009722 & 1954,286 \\
\hline 1,5 & 41 & 0,011389 & 1668,293 \\
\hline 2 & 50 & 0,013889 & 1368 \\
\hline 2,5 & 65 & 0,018056 & 1052,308 \\
\hline 3 & 112 & 0,031111 & 610,7143 \\
\hline 3,5 & 347 & 0,096389 & 197,1182 \\
\hline
\end{tabular}

Dari tabel 1.1 dapat dilihat bahwa pengambilan data dilakukan sebanyak 7 kali dengan memvariasi ketinggian dengan kenaikan 0,5 m. waktu pengisian galon dengan volume 19 Liter diukur menggunakan stopwatch. Waktu dalam satuan detik kemudian dikonversikan kedalam watuan jam. Sehingga dengan persamaan debit diperoleh debit air dari pompa submersible dalam satuan liter/jam. Dari tabel 1 juga dapat dilihat bahwa terjadi penurunan debit air seiring dengan kenaikan ketinggian galon. Untuk melihat dan menentukan persamaan yang menghubungkan antara ketinggian galon dengan debit air yang dihasilkan oleh pompa digunakan analisis grafik dengan Excel. Adapun garafik hubungan antara ketinggian galon (h) dengan debit air (Q) adalah sebagai berikut: 


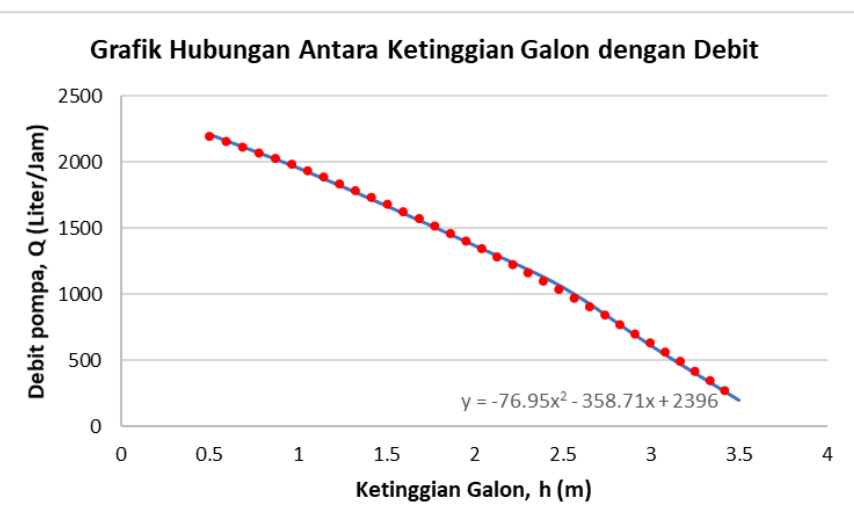

Gambar 3. Grafik Hubungan antara Ketinggian Galon terhadap Debit Pompa

Data debit air untuk berbagai ketinggian galon kemudian dihubungkan dengan grafik pada Excel. Kemudian dilakukan trendline option untuk melihat bagaimna pola/bentuk hubungan dua besaran tersebut. Dengan menggunakan polynomial order 2 diperoleh persamaan yang menghubungan debit air pada sumbu y dan ketinggian pada sumbu $x$. sehingga diperoleh persamaan:

$$
Q=-76,95 h^{2}-358,71 h+2396
$$

Dimana adalah debit air yang dihasilkan oleh pompa dan adalah ketinggian penampungan. Dengan menggunakan persamaan tersebut debit akan mendekati nilai nol jika ketinggian atau nilai $\mathrm{h}$ adalah 3,71 m. dengan kata lain, batas ketinggian maksimal penampungan yang dapat dijangkau oleh pompa submersible DC 12 Volt adalah $3,71 \mathrm{~m}$. hal ini berbeda dengan spesifikasi yang tertulis dipoma dimana ketinggian maksimum yang dapat dijangkau adalah $5 \mathrm{~m}$. Hal ini mungkin disebabkan karena ukuran diamater selang yang digunakan dalam penelitian ini adalah $3 / 4$ inci. Kemungkinan jika menggunakan selang dengan diameter lebih kecil maka dapat menjangkau ketinggian lebih dari 3,71 meter.

Selain itu, kapasitas aki yang digunakan juga dapat berpengaruh terhadap daya listrik yang diperoleh oleh aki. Untuk menghitung berapa lama penggunaan aki dapat menggunakan teori fisika dasar. Diketahui bahwa daya beban pompa yang digunakan adalah 50 Watt sedangkan spesfikasi aki adalah 12 V 20 Ah dengan kata lain tegangan aki 12 Volt DC dan kapasitasnya (K) adalah 20 Ah. Sehingga arus listrik DC yang dibutuhkan oleh pompa adalah

$$
I=\frac{P}{V}=\frac{50 \mathrm{~W}}{12 \mathrm{~V}}=4,17 \text { Ampere }
$$

Sehingga lama maksimum penggunaan aki diperoleh dengan membagi kapasitas aki dengan arus kemudian dikurangi dengan faktor diefesiensi aki sebesar 20\%. Sehingga

$$
t=\frac{K}{I}-20 \%=\frac{20 \mathrm{Ah}}{4,17 \mathrm{~A}}-0,96 \mathrm{Jam}=3,836 \mathrm{jam}
$$

Dengan durasi pengambilan data hanya sekitar 1,5 jam maka dapat disimpulkan bahwa daya aki masih dalam keadaan normal sehingga kekuatan dorongan pompa yang berbeda jauh dari spesifikasi yang ada tidak disebabkan oleh daya aki keluaran aki. Untuk membuktikan ini sebaiknya dilakukan pengukuran tegangan dan arus aki setiap saat menggunakan voltmeter dan ampremeter. Namun karna keterbatasan alat, maka hal tersebut tidak dilakukan.

Pada umumnya petani menggunakan tandon (bak penampungan air) dengan volume yang berbedabeda untuk pengairan tanaman palawija. Berbagai ukuran volume tandon telah banyak kita temukan dipasaran. Dengan asumsi ketinggian tandon adalah 3,5 meter maka tentu untuk mengisi tandon tersebut membutuhkan waktu yang berbeda-beda. Untuk tandon dengan ukuran volume yang besar maka kapasitas aki perlu diperbesar agar dapat mengisi penampungan air hingga penuh. Jenis aki dengan volume dan berat yang masih dapat dibawah kemana-mana adalah aki dengan spesifikasi 12 Volt 50 Ah yang dapat digunakan selama 9,59 jam. Sesuai dengan hasil analisis perhitungan berikut adalah waktu yang dibutuhkan untuk pengisian berbagai ukuran bak penampungan.

\begin{tabular}{|c|c|c|c|}
\hline $\begin{array}{l}\text { Volume } \\
\text { (Liter) }\end{array}$ & $\begin{array}{l}\text { Waktu } \\
\text { (Jam) }\end{array}$ & $\begin{array}{c}\text { Jenis Aki } \\
(\mathrm{V} ; \mathrm{Ah})\end{array}$ & Keterangan \\
\hline \multirow[t]{2}{*}{300} & \multirow[t]{2}{*}{1,52} & $12 \mathrm{~V} 20 \mathrm{Ah}$ & Sesuai \\
\hline & & $12 \mathrm{~V} 50 \mathrm{Ah}$ & Sesuai \\
\hline \multirow[t]{2}{*}{500} & \multirow[t]{2}{*}{2,54} & $12 \mathrm{~V} 20 \mathrm{Ah}$ & Sesuai \\
\hline & & $12 \mathrm{~V} 50 \mathrm{Ah}$ & Sesuai \\
\hline \multirow[t]{2}{*}{1100} & \multirow[t]{2}{*}{5,58} & $12 \mathrm{~V} 20 \mathrm{Ah}$ & Tidak Sesuai \\
\hline & & $12 \mathrm{~V} 50 \mathrm{Ah}$ & Sesuai \\
\hline \multirow[t]{2}{*}{2200} & \multirow[t]{2}{*}{11,16} & $12 \mathrm{~V} 20 \mathrm{Ah}$ & Tidak Sesuai \\
\hline & & $12 \mathrm{~V} 50 \mathrm{Ah}$ & Sesuai \\
\hline
\end{tabular}

Tabel 2. Lama pengisian dan spesifikasi aki yang sesuai dengan volume tandon 
Dari tabel 2 dapat dilihat bahwa semakin besar ukuran volume tandon maka lama pengisian tandon tersebut semakin besar juga. Sebenarnya, durasi pengisian dapat dikurangi dengan mengurangi ketinggian bak penampungan, namun tekanan hidrostatis yang dihasilkan air akan mengecil sehingga air tidak akan bisa mengalir dengan jauh. Hal ini kurang efektik untuk lahan tanaman yang cukup luas.

\subsection{Tahap Peran Mahasiswa}

Saat melaksanakan proyek ini, kelompok kami sebagai pelaku proyek membuat keputusan berdasarkan pengetahuan dan informasi kami dari literatur maupun pengalaman tim ketika menjadi guru fisika/asisten. Beberapa keputusan yang kami ambil misalnya, (i) tema topik dari proyek yang akan dilakukan, masalah dan solusi yang diberikan; (ii) jenis dan spesifikasi pompa, aki dan ukuran, diamater selang; (iii) untuk menguji produktivitas pompa kami tentukan besaran yang kami kaji yaitu debit air dan ketinggian. Ide dan keputusan yang dikembangkan oleh tim kami di atas membuat peserta proyek merasa lebih terlibat dalam proses tersebut. Setiap ide disampaikan terlebih dahulu kepada dosen selama proses pembelajaran.

\subsection{Tahap Refleksi}

Dalam pengerjaan proyek melalui PBL Standard Gold yang dikembangkan oleh Buck Institute of Technology [15], banyak pengalaman belajar yang kami memperoleh baik sebagai tim maupun secara individu. Konsep, metode, produk yang kami dapatkan diuji secara menyeluruh. Hal ini sesuai dengan pendapat Canra yang menyatakan dengan adanya PBL dosen dan tutor atau menantang tim untuk melakukan aktivitas fisik yang menantang di laboratorium sehingga proses pembelajaran terasa lebih bermakna dari sekedar pembelajaran teoritis [14].

Gold Standard PBL dapat meningkatkan keterampilan pemecahan masalah. Tim belajar untuk mengumpulkan data dan menemukan solusi yang paling efektif dan efisien untuk suatu masalah. Hal itu sesuai dengan pendapat Thomas yang menyatakan bahwa dengan PBL mengajarkan mahasiswa proses penyelesaian berbagai masalah dari informasi awal [15]. Harper menyatakan bahwa fokus pembelajaran proyek pada proses penyelidikan mendalam yang melibatkan proses tanya jawab yang panjang dan ketat, menggunakan sumber daya dan mengembangkan jawaban; dan fokus pada pertanyaan terbuka untuk memahami dan menangkap perhatian mahasiswa dalam mennyelesaikan proyek [15]. Selain itu Muskania \& Wilujeng menyampaikan bahwa PBL diawali dengan pemberian masalah oleh dosen membuat mahasiswa mampu menemukan sebuah produk akhir [17].

Penerapan Gold Standard PBL pada kegiatan eksperimen membuat tim terlatih untuk meningkatkan keterampilan berpikir kritis. Masalah dan pertanyaan awal diperoleh dan dikonsultasikan oleh para ahli, sehingga menimbulkan banyak pertanyaan baru dan cukup kompleks. Tim diminta untuk bisa berpikir kritis tentang pertanyaan tersebut. Hal ini sejalan dengan pendapat Hendrik \& Ihtiari yang menjelaskan bahwa proses pembelajaran berbasis proyek dalam suatu aplikasi mendukung pengembangan dan peningkatan kemampuan berpikir kritis mahasiswa [18].

Selain itu, Berkolaborasi dengan tim selama pembelajaran proyek merupakan kegiatan yang yang muncul. Astawa, Artini, \& Nitiasih menjelaskan tahap pembelajaran proyek melatih mahasiswa untuk aktif dan berpikir kreatif serta terlibat dalam berkolaborasi dalam proyek [19]. Pembelajaran berbasis proyek memungkinkan mahasiswa untuk mendapatkan pemahaman yang lebih dalam tentang materi dengan berkolaborasi dan menggunakan ide-ide mereka. Interaksi sosial memungkinkan mahasiswa untuk bekerja dengan orang lain untuk membangun pengetahuan bersama. Williams menjelaskan bahwa pembelajaran berbasis proyek memberikan kesempatan kepada mahasiswa untuk terlibat aktif selama pembelajaran dan kesempatan untuk mempelajari soft skill baru seperti keterampilan seperti kolaborasi, komunikasi, dan negosiasi [20]. Selain itu, See et al menyatakan bahwa keterampilan komunikasi dan kerjasama tim merupakan keterampilan yang dapat dilatihkan melalui kegiatan proyek [21]. 
Selain poin-poin di atas, metode $\mathrm{PBL}$ juga berhasil melatih mahasiswa dalam beberapa soft skill, diantaranya kemampuan memutuskan dan mempertimbangkan sesuatu untuk mengevaluasi kemajuan pekerjaan dan mengembangkan berpikir kritis. Selain itu, PBL juga memberikan pengalaman berharga tentang bagaimana dibimbing oleh para ahli untuk menemukan masalah dan menyelesaikannya dengan langkahlangkah ilmiah. Dengan berbagai refleksi yang disebutkan di atas, tim kami berharap kemampuan ini dapat bermanfaat untuk pengembangan individu masing-masing peserta proyek, serta untuk lebih mengembangkan produk yang kami rancang di masa mendatang.

\subsection{Tahap Kritik dan Revisi}

Selama pengerjaan proyek, tim menerima banyak pengalaman dan saran dari para dosen. Kritik dan saran ini untuk kepentingan proyek kami saat ini, serta pengembangan masa depan. Beberapa catatan yang diberikan oleh dosen yaitu: (i) dilakukan pengambilan data lebih banyak dengan memvariasikan diamater selang, sebab hal ini sangat berpengaruh terhadap debit air; (ii) selama proses pengambilan data, tim sebaiknya menjagga daya aki/baterei dengan memasangkan alat pengukur arus; Namun karena keterbatasan waktu dan dana, maka kritik dan saran tersebut belum dilakukan perbaikin. Hal ini dapat menjadi pekerjaan lanjutan bagi mahasiswa atau peneliti lainnya.

\subsection{Tahap Publikasi Produk}

Produk yang dihasilkan dalam Pembelajaran Berbasis Proyek ini disebut "Perangkat Percobaan Uji Produktivitas Pompa DC 12 volt 50 watt." Dari produk ini kemudian diperoleh persamaan yang menghubungkan variabel debit air dan ketinggian bak penampungan. Proses selanjutnya yang harus diikuti untuk menerapkan Gold Standard PBL adalah penyajian (publiskasi) hasil proyek didepan tim lain, tutor dan dosen.

\section{Kesimpulan}

Dengan mengikuti tahapan Gold Standar Project Based Learning tim berhasil melakukan uji coba terhadap pompa untuk mengetahui produktivitasnnya berdasarkan data debit pada berbagai ketinggian bak penampungan air.
Berdasarkan hasil pengambilan data dan analisi maka dapat disimpulkan bahwa terjadi penurunan debit air jika terjadi kenaikan tinggi bak penampungan yang dirumuskan dalam persamaan kuadrat. Dengan menggukan selang dengan ukuran diamater $3 / 4$ inci maka diperoleh ketinggian maksimum bak yang dapat dijangkau oleh pompa DC 12 Volt 50 Watt adalah 3,71 meter. Hal ini berbeda dengan spesfikasi pompa yang mampu mendorong air dengan ketinggian $5 \mathrm{~m}$.

Hal ini kemungkinan disebabkan oleh dua hal yaitu (1) diamater selang sebaiknya menggunakan diameter yang lebih kecil agar jangkauan (kecepatan) aliran air lebih besar dan (2) mengontrol arus dari aki menggunakan ampremeter, sehingga ketika terjadi penurunan arus, peneliti dapat melakukan pengecasan terlebih dahulu sebelum melanjutkan pengambilan data. Oleh karena itu perlu dilakukan penelitian lanjutan untuk mengetahui hubungan antara ketinggian bak penampungan dengan debit air yang dihasilkan oleh pompa celup menggunakan berbagai jenis ukuran selang. Selain itu, agar daya aki tidak berkurang selama penggunaan pompa maka aki dapat disambungkan dengan panel surya sehingga proses penggunaan pompa bisa lebih lama. Penelitian lanjutan dapat juga mengkaji bagaimana hubungan dorongan pompa untuk selang yang diletakkan secara horizontal.

Hasil penelitian ini dapat menjadi rujukan bagi pengajar baik guru, tutor atau dosen untuk menerapkan pembelajaran berbasis proyek dalam pembelajaran fisika. Berbagai macam penelitian lanjutan dapat dilakukan untuk menguji keefektifan model pembelajaran berbasis proyek dengan melibatkan mahasiswa sebagai sampel penelitian. Sebagai contoh bagaimana profil keterampilan proses sains, kemampuan pemecahan masalah mahasiswa setelah mengikuti pembelajaran mata kuliah yang mengkombinasikan pembelajaran teori dalam kelas dan pembelajaran proyek di laboratorium atau lapangan..

\section{Daftar Pustaka}

[1] N. Azhar, B. Hussain, M. Y. Ashraf, and K. Y. Abbasi, "Water stress mediated changes in growth, physiology and secondary 
metabolites of desi ajwain (Trachyspermum Ammi L.)," Pakistan J. Bot., vol. 43, no. SPEC. ISSUE, pp. 15-19, 2011.

[2] H. Pratiwi, "Pengaruh kekeringan pada berbagai fase tumbuh kacang tanah," Bul. Palawija, vol. 22, no. 22, pp. 71-78, 2011.

[3] M. Saputra, A. Yusra, and A. Syuhada, "Kajian Penggunaan Energi Surya Dan Energi Bayu Sebagai Penggerak Pompa Air-Tanah Untuk Pengairan Pertanian," vol. 3, no. 5, pp. 118-127, 2017.

[4] A. L. Rettob and R. S. Waremra, "Pompa Air Bertenaga Energi Matahari (Solar Cell) Untuk Pengairan Sawah," Musamus J. Sci. Educ., vol. 1, no. 2, pp. 046-052, 2019.

[5] C. Sari, B. Fandidarma, and N. Solikin, "Pompa Air Harapan: Upaya Penanggulangan Kekeringan dan Pengembangan Usaha Mandiri Masyarakat Desa Kwadungan Lor, Kabupaten Ngawi," War. Pengabdi., vol. 14, no. 3, p. 164, 2020.

[6] F. Saputra, "Kinerja Pompa Air DC Berdasarkan Intensitas Tenaga Surya," 2015.

[7] P. Widodo and D. A. Nasution, "Rekayasa Disain Pompa Tenaga Surya Untuk Irigasi Budidaya Bawang Merah Di Lahan Kering," Pros. Semin. Nas. Teknol. Pertan., vol. 0, no. 0, pp. 292-298, 2016.

[8] R. Sinaga and M. F. M. Ratu, "Simulasi Pengujian Karakteristik Pompa Air Menggunakan Catu Daya Modul Surya Dan Baterai Siklus Dalam," 2019.

[9] A. Y. C. Bambang Setiawan, Gunawan Hidayat, "Rancang Bangun Dc Submersible Pump Sistem Photovoltaic Battery Coupled Dengan Panel Surya Tipe Polycrystalline Skala Laboratorium," Semin. Nas. Sains dan Teknol., no. TM-019, pp. 1-8, 2017.

[10] K. L. Yana, K. R. Dantes, and N. A. Wigraha, "Rancang Bangun Mesin Pompa Air Dengan Sistem Recharging," J. Pendidik. Tek. Mesin Undiksha, vol. 5, no. 2, 2017.
[11] Usman, A. Sunding, and A. N. Parawangsa, "Analisis Kinerja dan Ekonomi Sistem Pompa Air Tenaga Surya Skala Laboratorium Abstrak," J. Teknol. Terap., vol. 4, no. 1, Maret 2018, pp. 12-18, 2018.

[12] C. Hermanu, B. Apribowo, T. E. S, and M. Anwar, "Prototype Sistem Pompa Air Tenaga Surya Untuk Meningkatkan Produktivitas Hasil Pertanian," J. Abdimas, vol. 21, no. 2, pp. 97-102, 2017.

[13] S. Bagi, K. Rejo, and N. Soedjarwanto, "Pompa Air Tenaga Surya Untuk Irigasi Per- Masyarakat Desa Karang Rejo, Pesaweran, Lampung",Wikrama Parahita: Jurnal Pengabdian Masyaraka 2021.

[14] R. Candra, N. Flaminggo, A. Natalia, E. Yuliza, and K. Khairurrijal, "Making Counter Clockwise Analog Thermometer under Project-based Learning Method," J. Phys. Conf. Ser., vol. 1204, no. 1, 2019.

[15] A. Swandi, F. Afrianto, and S. Rahmadhanningsih, "Project Based Learning Based on Laboratory Experiments to Produce Laser Diffraction Experimental Devices on CD and DVD with 2 Measurement Methods", Indonesian Journal of Eeducational Studies., vol. 23, no. 2, pp. 108-117, 2020.

[16] Gunawan, A. Harjono, and H. Sahidu, "Pengembangan Model Laboratorium Virtual Berorientasi Pada Kemampuan Pemecahan Masalah Bagi Calon Guru Fisika," Pros. Semin. Nas. Fis. dan Pendidik. Fis., vol. 6, no. 1, pp. 232-237, 2015.

[17] R. Tesi Muskania and I. Wilujeng, "Pengembangan Perangkat Pembelajaran Project-Based Learning Untuk Membekali Foundational Knowledge Dan Meningkatkanscientificliteracy," J. Cakrawala Pendidik., vol. 36, no. 1, pp. 3443, 2017.

[18] W. Sumarni, "The Strenghths and Weaknesess of the Implementation of Project Based Learning: A Review," Int. J. Sci. Res., vol. 4, no. 3, pp. 478-484, 2015. 
[19] N. L. P. N. S. P. Astawa, L. P. Artini, and P. K. Nitiasih, "Project-based Learning Activities and EFL Students' Productive Skills in English," J. Lang. Teach. Res., vol. 8, no. 6, p. 1147, 2017.

[20] S. Williams, "Investigating the allocation and corroboration of individual grades for project-based learning," Stud. Educ. Eval., vol. 53, no. June 2017, pp. 1-9, 2017.

[21] Y. G. See, A. M. Rashid, and A. R. Bakar, "The Effect of Project Based Learning on Level of Content Knowledge of PreVocational Subject," Mediterr. J. Soc. Sci., vol. 6, no. 6, pp. 369-375, 2015. 